\title{
PENGARUH PENGELUARAN PEMERINTAH DAERAH PADA SEKTOR PENDIDIKAN DAN KESEHATAN TERHADAP INDEKS PEMBANGUNAN MANUSIA DI INDONESIA
}

\author{
Meylina Astri, S.Pd. \\ (Alumni Fakultas Ekonomi UNJ) \\ Sri Indah Nikensari, SE, M.Si \\ (Dosen Fakultas Ekonomi UNJ) \\ Dr. Harya Kuncara W. SE, M.Si \\ (Dosen Fakultas Ekonomi UNJ)
}

\begin{abstract}
ABSTRAK
Penelitian ini bertujuan untuk mengetahui pengaruh variabel-variabelpengeluaran pemerintah daerah pada sektor pendidikan dan kesehatan terhadap Indeks Pembangunan Manusia (IPM). Penelitian ini dilakukan dengan memperhatikan perkembangan pengeluaran pemerintah di Indonesia khususnya jangka waktu 20072008 dengan metode statistik inferensial (induktif). Jenis data yang digunakan adalah data time series, dengan data sekunder yang dipublikasi oleh Biro Pusat Statistik (BPS) dan lembaga lainnya. Pengolahan data dengan menggunakan program SPSS 17.0. Hasil dari persamaan regresi berganda yang didapat dalam penelitian ini adalah $\mathrm{Y}=42,955+0,902 \mathrm{LnX} \mathrm{X}_{1}+0,198 \mathrm{LnX} \mathrm{X}_{2}$. Dari Uji $\mathrm{F}$ pengaruh pengeluaran pemerintah daerah pada sektor pendidikan dan kesehatan terhadap Indeks Pembangunan Manusia, $F$ hitung adalah sebesar 6,074 sedangkan $F$ tabel adalah sebesar 3,171626 maka $F_{\text {hitung }}>F_{\text {tabel. }}$. Artinya terdapat pengaruh pengeluaran pemerintah daerah pada sektor pendidikan dan kesehatan terhadap Indeks Pembangunan Manusia secara serempak Kesimpulan yang sama terjadi pada uji signifikansi dan nilai sig. Yang didapat adalah 0,004 dari hasil tersebut bahwa sig. lebih kecil dari a maka Ho ditolak, artinya terdapat pengaruh pengeluaran pemerintah daerah pada sektor pendidikan dan kesehatan terhadap Indeks Pembangunan Manusia. Untuk uji t, dari hasil perhitungan dapat disimpulkan bahwa secara parsial variabel pengeluaran pemerintah daerah pada sektor pendidikan berpengaruh pada IPM ( $\mathrm{t}$ hitung 3,023 > $\mathrm{t}$ tabel1,674116), namun pengeluaran pemerintah daerah pada sektor kesehatan tidak berpengaruh pada IPM ( $t$ hitung $0,412<t$ tabel 1,674116$)$. Selain itu, terlihat bahwa nilai $R$ Square adalah sebesar 0,186 , artinya seluruh variabel bebas (pengeluaran pemerintah daerah pada sektor pendidikan dan kesehatan) dapat menjelaskan variabel terikat (Indeks Pembangunan Manusia) sebesar $18,6 \%$. Sedangkan sisanya sebesar $81,4 \%$ diterangkan oleh variabel lain.
\end{abstract}

\section{PENDAHULUAN}

Persaingan adalah tuntutan dan tantangan zaman. Memiliki kualitas unggul pada sumber daya manusia adalah tanggung jawab moral yang harus dijawab bangsa Indonesia. Berdasarkan hasil Human Development Index (HDI) UNDP pada tahun 2009, posisi Indonesia dalam peringkat daya saing bangsa di dunia Internasional 
berada diperingkat 111 dari 182 negara. Indonesia berada jauh dibawah negara tetangga terdekatnya yaitu Malaysia yang menduduki posisi ke-66 dari 182 negara.

Dibandingkan dengan tahun sebelumnya, pada tahun 2007 indeks pembangunan manusia Indonesiamenempati peringkat 108 pada dari 182 negara, dengan kata lain IPM Indonesia mengalami penurunan pada tahun 2009.Bahkan menurut majalah AS, Forbes Policy, Indonesia termasuk kedalam kategori negara yang gagal di tahun 2007, karena Negara Indonesia berada di urutan 55 dengan skor 84,4 dari 60 negara yang masuk dalam perhitungan. Fakta angka ini menunjukkan bahwa Indonesia masih cukup tertinggal dan kesulitan untuk bisa bersaing dengan negaranegara lainnya, khususnya dengan negara tetangga kita yang sudah sedemikian maju perkembangannya.

Adapun peringkat Indeks Pembangunan Manusia Indonesia dapat dilihat pada table berikut:
Tabel 1

Indeks Pembangunan Manusia Indonesia

\begin{tabular}{|c|c|}
\hline Tahun & $\begin{array}{c}\text { Indeks } \\
\text { Pembangunan } \\
\text { Manusia }\end{array}$ \\
\hline 1996 & 67,7 \\
\hline 1999 & 64,3 \\
\hline 2002 & 65,8 \\
\hline 2004 & 68,7 \\
\hline 2005 & 69,57 \\
\hline 2006 & 70,10 \\
\hline 2007 & 70,59 \\
\hline 2008 & 71,17 \\
\hline & Sumber BPS \\
\hline
\end{tabular}

Data di atas jelas mendeskripsikan perkembangan indeks pembangunan manusia Indonesia mengalami peningkatan dari tahun ke tahunnya. Ini merupakan hal positif bagi bangsa Indonesia dalam membentuk sumber daya manusia yang unggul, akan tetapi jika dinilai perbandingannya dengan negara-negara di benua Eropa, Amerika, Australia, dan bahkan Asia, Indonesia masih jauh tertinggal. Oleh karena itu, diperlukan upaya khusus yang menyeluruh dari pemerintah dan juga setiap penduduk di Indonesia untuk meningkatkan kualitas setiap anak bangsa. Hal tersebut harus mulai diperbaiki pada setiap daerah dan provinsi diseluruh Indonesia.

Sejak tahun 2001 telah terjadi perubahan yang cukup fundamental 
dalam mekanisme penyelenggaraan pemerintahan di Indonesia. Perubahan tersebut terkait dengan dilaksanakannya otonomi daerah sebagaimana yang diamanatkan dalam UU Nomor 22 Tahun 1999 tentang Pemerintahan Daerah yang telah direvisi dengan UU Nomor 32 Tahun 2004. Undang-Undang di bidang otonomi daerah tersebut telah menetapkan pemberian kewenangan otonomi dalam wujud otonomi yang luas, nyata, dan bertanggung jawab kepada daerah untuk menetapkan prioritas pembangunan dan mengelola segala potensi daerah dan pemberdayaan sumber daya setempat sesuai dengan kepentingan masyarakat.Implikasi dari kewenangan otonomi daerah menuntut daerah untuk melaksanakan pembangunan di segala bidang, terutama untuk pembangunan sarana dan prasarana publik (public service), yang dengan kata lain mensyaratkan adanya kebijakan pengeluaran pemerintah daerah yang mandiri dan professional dalam investasi publik.

Dengan berlakunya Undang No. 32 Tahun 2004 tentang Pemerintah Daerah, maka daerah otonomi diberikan kewenangan mengatur dan mengurus semua urusan pemerintahan di luar yang menjadi urusan Pemerintahan Pusat, untuk memberi pelayanan, peningkatan peran serta, prakarsa dan pemberdayaan masyarakat yang bertujuan pada peningkatan kesejahteraan masyarakat. Dengan makna bahwa daerah diberi kewenangan untuk mengatur, mengelola dan melaksanakan pembangunan daerah atas dasar potensi yang dimiliki daerah, yang mengartikan secara langsung maju mundurnya suatu daerah sangat ditentukan oleh komponen masyarakat daerah yang bersangkutan. Salah satu instrumen kebijakan yang penting ialah APBD dengan pengaturan distribusi anggarannya.

Besar kuantitas penduduk Indonesia yang tercatat pada sensus penduduk Indonesia pada tahun 2005 adalah 220 juta jiwa, dan diperkirakan pada tahun 2009 meningkat 1,29\% yakni menyentuh angka 231 juta jiwa. Penambahan jumlah penduduk yang besar tersebut menurut Sumarjati Arjoso mempunyai implikasi yang sangat luas terhadap program pembangunan manusia. Penduduk yang besar dengan kualitas yang relatif kurang memadai sangat berpotensi memberikan beban dalam pembangunan di Indonesi. Beban pembangunan tersebut antara lain tercermin melalui beratnya beban pemerintah pusat dan daerah untuk menyediakan berbagai pelayanan 
publik seperti pendidikan, kesehatan, perumahan, lapangan kerja, lingkungan hidup dan sebagainya. Oleh karena itu, betapa pentingnya pembangunan manusia di Indonesia untuk meningkatkan kualitas sumber daya manusia.

Pada kenyataan empiris di lapangan, pemerintah daerah memiliki peluang yang terbatas untuk mengambil keputusan mengenai pengeluaran untuk kebutuhan daerah. Pada tahun 2007 pemerintah provinsi hanya mengelola sekitar 15 persen dari pengeluaran publik untuk sektor kesehatan. Sedikitsekali ruang yang tersedia untuk realokasi, dan sebagai akibatnya, sedikit sekali ruang lingkup pilihan pembiayaan atau diskresi dalam pengawasan kegiatan kesehatan masyarakat.Meskipun terdapat peningkatan cukup substansial selama beberapa tahun terakhir, Namun Pemerintah Indonesia masih mengeluarkan uang yang relatif sedikit untuk kesehatan. Secara keseluruhan, Indonesia mengeluarkan kurang dari 3 persendari PDB-nya untuk sektor kesehatan (terdiri dari 2 persen pengeluaran swastadan 1 persen pengeluaran pemerintah).

Pengeluaran pemerintah propinsi pada sektor pendidikan dan kesehatan pada umumnya mengalami kenaikan, namun besarannya masih dibawah pengeluaran pemerintah pada sektor industri, perumahan dan pemukiman, serta sektor ekonomi lainnya.Jelas ini mesdeskripsikan bahwa pemerintah Indonesia masih kurang perhatian terhadap sektor pendidikan dan kesehatan.

Ranah pembangunan manusia melalui sektor pendidikan turut dipertimbangkan, karena melalui pendidikan manusia mengalami sebuah proses. Proses tersebut dilalui oleh manusia untuk meningkatkan ilmu, pengetahuan, kemampuan/keahlian, meningkatkan kreativitas ataupun inovasi yang keseluruhannya dapat meningkatkan harkat dan martabat setiap individu. Pendidikan terlihat sebagai investasi sumber daya saat ini untuk mendapatkan return dimasa depan. Apabila kualitas sumber daya manusia tersebut rendah yang tercermin adalah tingkat pendidikan dan kesehatan yang rendah pula yang tentunya berpengaruh juga pada pembangunan manusia. Senada dengan ranah pemikiran Schultz beragumentasi bahwa: pengetahuan dan skill adalah bentuk dari capital, yang akan menghasilkan "deliberate investment". Investasi dalam pendidikan formal, training, dan kesehatan akan meningkatkan kesempatan dan pilihan bagi individu, yang akan mempengaruhi kemampuan 
untuk melakukan pekerjaan yang produktif.

Pengeluaran pemerintah sektor pendidikan dan kesehatan merupakan dua dari beberapa faktor yang mempengaruhi pembangunan manusia. Kedua faktor tersebut, merupakan layanan jasa yang normatifnya disediakan oleh pemerintah, bukan bertumpu pada swasta terlebih pasar.Dalam hal peningkatan pembangunan manusia, pendidikan dan kesehatan yang baik bagi setiap manusia bisa terwujud melalui alokasi pengeluaran pemerintah di sektor pendidikan dan kesehatan. Dengan meningkatnya alokasi pengeluaran pemerintah disektor tersebut maka akan meningkatkan prioduktivitas penduduk sehingga bisa meningkatkan pembangunan manusia. Untuk selanjutnya, pengeluaran pemerintah pada sektor pendidikan dan kesehatan dapat disebut sebagai investasi publik.

Usaha untuk meningkatkan IPM di Indonesia, tidak hanya berhenti pada usaha peningkatan pengeluaran pemerintah pada sektor pendidikan dan kesehatan di Indonesia. Pendapat tersebut tidaklah tanpa alasan, karena terdapat permasalahan lain yang juga membutuhkan perhatian, yaitu permasalahan rendahnya produktivitas masyarakat Indonesia. Rendahnya produktivitas masyarakat secara akumulatif pasti akan berimbas pada pencapaian PDB (Produk Domestik Bruto) atau memperlambat akselerasi pertumbuhan yang berujung pada rendahnya pembangunan manusia di Indonesia.Jika dilihat pada tataran masyarakat daerah, tingkat produktivitas dapat dilihat dari PDRB (Produk Domestik Regional Bruto).

Strategi pembangunan manusia di Indonesia merupakan upaya meningkatkan kesediaan akses bagi setiap individu guna memenuhi setiap kebutuhan hidupnya. Akses yang dimaksud adalah, jangkauan yang dapat diperoleh oleh setiap individu guna melanjutkan kehidupan yang berkualitas. Masalah keterbatasan akses yang seringkali menjadi masalah mayoritas insan, adalah keterbatasan dalam pemenuhan akses dari sisi fisik dan non-fisik. Akses fisik berupa pemenuhan konsumsi setiap barang/benda, sedangkan akses nonfisik berupa jangkauan setiap individu terhadap telekomunikasi, pendidikan, kesehatan, dan lain-lain.

$$
\text { Perolehan angka rata-rata }
$$
konsumsi protein hewani masih dilihat pada scope nasional, jika angka statistik tersebut dapat lebih rinci lagi menggambarkan tingkat konsumsi protein hewani disetiap daerah di Indonesia, maka akan terlihat jelas ketimpangan antar provinsi di 
Indonesia. Oleh karena itu, peran pangan asal hewani dan nabati sangat besar dalam mewujudkan masyarakat yang lebih sehat dan lebih pintar (healthier and brighter society), yang pada akhirnya akan meningkatkan IPM.

Proses pendidikan yang berkesinambungan tanpa memihak satu golongan minoritas, peningkatan layanan dan tingkat kesehatan masyarakat dengan meningkatkan investasi publik melalui pengeluaran pemerintah, meningkatkan produktivitas masyarakat Indonesia, pemerataan akses,serta meningkatkan konsumsi masyarakat, merupakan beberapa cara yang efektif dan efisien guna meningkatkan Indeks Pembangunan Manusia di Indonesia yang masih berada pada posisi memprihatinkan, jika dibandingkan dengan negaranegara di dunia.

Berdasarkan permasalahan ini maka peneliti tertarik untuk mengadakan penelitian tentang "Pengaruh Pengeluaran Pemerintah Daerah Pada Sektor Pendidikan dan Kesehatan Terhadap Indeks Pembangunan Manusia (IPM) setiap Provinsi di Indonesia".

\section{KAJIAN TEORI}

\section{Hakikat Pembangunan Manusia}

Paradigma pembangunan adalah suatu proses menyeluruh yang menyentuh seluruh aspek, baik ekonomi, sosial, budaya, hukum, dan lainnya. Pembangunan merupakan cara pandang terhadap suatu persoalan pembangunan, dalam arti pembangunan baik sebagai proses maupun sebagai metode untuk mencapai peningkatan kualitas hidup manusia dan kesejahteraan rakyat. Paradigma pembangunan di Indonesia mengalami perkembangan dari beberapa tahap sebagai berikut: pertama, paradigma pertumbuhan (growth paradigm); kedua, pergeseran dari paradigma pertumbuhan menjadi paradigm kesejahteraan (Welfare paradigm); dan ketiga, paradigma pembangunan yang berpusat ada manusia (people centered development paradigm)

Pendapat Owens (1987) yang dikutip oleh Martinus Nanang: hal terpenting adalah pembangunan manusia, bukan pembangunan benda (the development of people rather than the development of things), karena nilai balik riil pembangunan manusia memberikan sumbangan lebih kuur pada pembangunan dibandingkan pada pembangunan benda (fisik).

Menurut UNDP pada tahun 1990 yang dikutip oleh Suparman, pembangunan manusia adalah:

"Human development is a process of enlarging people's choices. In 
principle,these choice can be infinite and change over timt. But at all levels of development, the three assential ones are peope to lead a long and healthy life, to aquire knowledge and to have access to resourses needed for a decent standard of living. Additional choicec include political freedom, guaranteed human rights and personal self respect. If these essential choices are ot available, many other opportunities remain inaccessible. The most critical of these wide ranging choices are to live along and healthy life, to be educated and to have acces to resources needed for a decent standard of living"

IPM (Indeks Pembangunan Manusia) disusun dari komponen pembangunan manusia yang dianggap menjadi dasar yaitu:

1. Ketahanan Hidup/Usia Hidup (Longevity), diukur dengan harapan hidup pada saat lahir

2. Pendidikan yang dihitung berdasarkan tingkat rata-rata melek huruf dikalangan penduduk dewasa (bobotnya dua pertiga) dan angka rata-rata lama sekolah (bobotnya sepertiga)

3. Kualitas standar hidup yang diukur berdasarkan pendapatan perkapita riil yang disesuaikan dengan paritas daya beli dari mata uang domestic dimasing-masing Negara
Secara Matematis, rumus penghitungan IPM akan dipaparkan secara lengkapnya dari awal proses perhitungan per-indeks, yakni:

$\mathrm{IPM}=1 / 3(X(1)+X(2)+X(3))$

$$
X_{(1)}=\frac{L E-25}{85-25}
$$

$$
\begin{aligned}
& X_{(2)}=\underline{2} \times \text { ALI }+\underline{1} \times \text { GER } \\
& \text { ALI }=\frac{\text { ALR }-0}{100-0} \\
& \text { GER }=\frac{\text { CGER }-0}{100-0} \\
& X_{(3)}=\frac{\log (G D P p c)-\log (100)}{\log (40.000)-\log (100)}
\end{aligned}
$$

Dimana;

X(1): Indeks Harapan Hidup

$X(2)$ : Indeks Pendidikan $=2 / 3$ (indeks melek huruf) $+1 / 3$ (indeks rata-rata lama sekolah)

$X(3)$ : Indeks standar hidup layak

LE : Life Expetancy

ALI : Adult Literacy Rate

CGER: Combined Gross Enrollment Ratio

GDPpc: GDP percapita Indeks masing-masing komponen IPM tersebut merupakan perbandingan antara selisih suatu nilai maksimum dan nilai minimum indicator yang bersangkutan, atau bisa ditulis sebagai berikut :

Indeks $X(\mathrm{i})=\mathrm{X}(\mathrm{i})-\mathrm{X}(\mathrm{i}) \min / \mathrm{X}(\mathrm{i})$ maks $X(i) \min$

Dimana : 
$\mathrm{X}(\mathrm{i}) \quad$ : indikator ke-i $(\mathrm{i}=1,2,3)$

$\mathrm{X}$ (i)maks: nilai maksimum $\mathrm{X}$ (i)

$X(i)$ min: nilai minimum $X(i)$

Nilai maksimum dan minimum masing-masing indikator diatas, merupakan nilai maksimum dan minimum yang menjadi standar global yang ditetapkan UNDP. Dengan demikian tinggi rendahnya indeks masing-masing indikator yang bisa dihasilkan suatu negara pada satu tahun, menunjukkan tinggi rendahnya tingkat keberhasilan pembangunan manusia yang bisa dicapai negara tersebut.Indeks tersebut menjadi sesuatu yang penting sebagai alternative dalam pengukuran pembangunan (yang lebih menekankan pada manusia bukan pertumbuhan semata yang diukur dari GDP) yang selama ini.

\section{Hakikat Pengeluaran Pemerintah} Daerah Pada Sektor Pendidikan

Menurut Baswir (1999) yang dikutip oleh Budi D. Sinulingga, secara umum anggaran pemerintah dapat diartikan sebagai rencana keuangan yang mencerminkan pilihan kebijaksanaan untuk suatu periode suatu periode dimasa yang akan datang. Struktur anggaran sendiri menggambarkan pengelompokkan komponen-komponen anggaran berdasarkan suatu kerangka tertentu.
Berdasarkan struktur anggaran yang dipakai sekarang, maka anggaran pemerintah daerah dinamakan anggaran terpilih. Struktur anggaran pemerintah, dalam sistem anggaran di Indonesia dikenal dua macam pengeluaran pemerintah yaitu pengeluaran rutin dan pengeluaran pembangunan. Pengeluaran rutin adalah pengeluaran untuk operasionalisasi pemerintah seperti halnya untuk pembayaran gaji pegawai dan lainnya. Pengeluaran pembangunan adalah pengeluaran yang dikategorikan sebagai pengeluaran untuk investasi pemerintah, diantaranya investasi disektor pendidikan dan kesehatan (publik).

Menurut Halim

(2007) pengelolaan keuangan daerah adalah keseluruhan kegiatan yang meliputi perencanaan, pelaksanaan, penatausahaan, pelaporan, pertanggungjawaban dan pengawasan keuangan daerah. Berdasarkan Undang-Undang No 33 Tahun 2004 Pasal 66 ayat 1, keuangan daerah harus dikelola secara tertib, taat pada peraturan perundang-undangan, efisien, ekonomis, efektif, transparan dan bertanggungjawab dengan memperhatikan keadilan, kepatutan dan manfaat untuk masyarakat. Oleh karena itu pengelolaan keuangan 
daerah dilaksanakan dengan pendekatan kinerja yang berorientasi pada output dengan menggunakan konsep nilai uang (value for money) serta prinsip tata pemerintahan yang baik (good governance). Pengelolaan anggaran adalah suatu tindakan penyeimbangan berbagai kebutuhan. Kebutuhan di bidang pendidikan, sosial, dan kesehatan menjadi tanggung jawab pemerintah daerah, untuk mencukupi kebutuhan pembiayaan di sektor public tersebut pemerintah mengoptimalkan sumber-sumber penerimaan daerahnya sendiri. Sehingga dengan otonomi daerah pemerintah daerah akan semakin mampu mencukupi kebutuhan pembangunannya.

\section{Hakikat Pengeluaran Pemerintah Daerah Pada Sektor Kesehatan}

Dalam UUD 1945 disebutkan kesehatan merupakan hak dasar (azasi) manusia, sehingga pemerintah bertanggungjawab memenuhi kebutuhan perlindungan dan fasilitasi kesehatan kepada rakyatnya. Apalagi dalam tujuan pembangunan nasional telah disebutkan setiap penduduk berhak memperoleh derajat kesehatan yang setinggi-tingginya. Maka wajar jika kesehatan dapat disebut sebagai investasi pemerintah pada belanja/pegeluaran pembangunan untuk pengembangan sumber daya manusia.

Pengeluaran pemerintah pada sektor kesehatan merupakan upaya untuk memenuhi salah satu hak dasar rakyat, yaitu hak untuk memperoleh pelayanan kesehatan sesuai dengan Undang-Undang Dasar 1945 Pasal 28 $\mathrm{H}$ ayat (1) dan Undang-undang Nomor 23 Tahun 1992 tentang Kesehatan. Prioritas kesehatan harus dipandang sebagai suatu investasi untuk peningkatan kualitas sumber daya manusia.

Menurut Lains dan Pasay yang lebih menekankan aspek pendidikan dalam pembangunan manusia, Tjiptoherijanto (1989) melihat mutu manusia dari sisi lain yaitu dari sisi kesehatan dimana kesehatan merupakan salah satu faktor yang mempengaruhi sumberdayamanusia, dengan kata lain aspek kesehatan turut mempengaruhi kualitas manusia. Kekurangan kalori, gizi, ataupun rendahnya derajat kesehatan bagi penduduk akan menghasilkan kualitas manusia yang rendah dengan tingkat mental yang terbelakang. Oleh karena itu, diperlukan anggaran khusus untuk meningkatkan pelayanan kesehatan bagi masyarakat melalui pengeluaran pemerintah.

Purcal dan Cohen menyatakan bahwa, betapa paradigma kesehatan di 
Indonesia memang jauh tertinggal dibanding negara-negara anggota ASEAN lainnya. Singapura, Malaysia, Thailand, Brunei Darussalam, bahkan Vietnam sejak beberapa tahun lalu mulai melihat dan menempatkan masalah kesehatan sebagai investasi jangka panjang (long term human investment), sementara Indonesia masih saja sulit beranjak dari paradigma lama, kesehatan sekadar sebagai konsums. Konsekuensi dari paradigma usang kesehatan sebagai konsumsi itu antara lain berupa pengabaian masalah kesehatan dalam prioritas anggaran pembangunan

Berdasarkan teori dan penelitian empiris yang telah dikemukakan di atas, maka untuk mengetahui pengaruh pengeluaran pemerintah pada sektor pendidikan dan pengeluaran pemerintah pada sektor kesehatan terhadap indekspembangunan manusia Indonesia, dapat dikemukakan pada kerangka berpikir yang dirumuskan seperti dalam gambar 1 berikut ini:

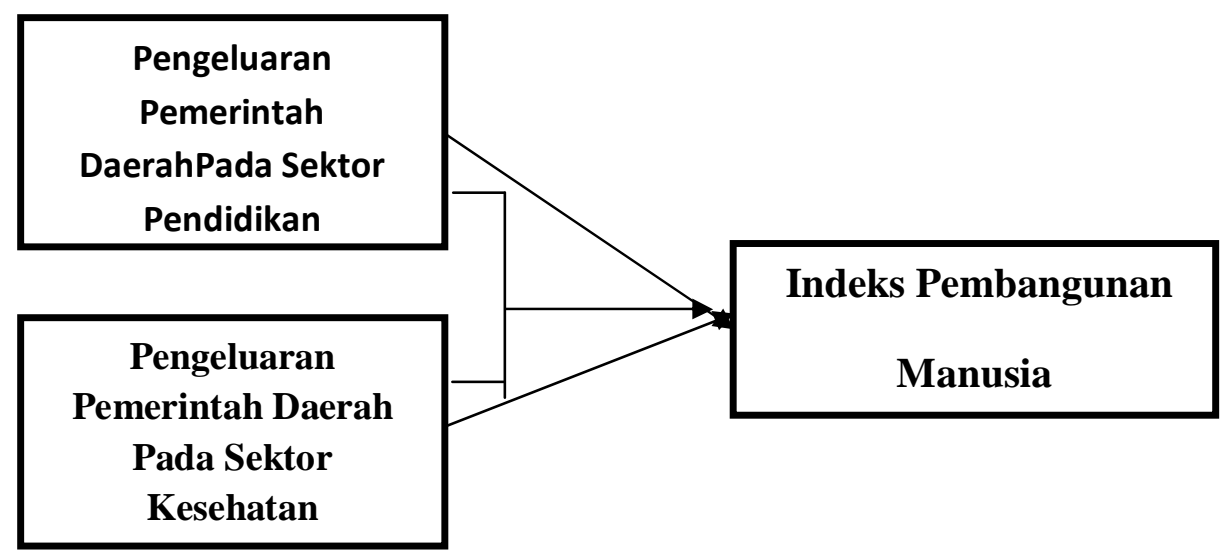

Gambar 3.1

Kerangka Berpikir

Akumulasi

pemerintah

pada

pengeluaran

pembangunan, merupakan investasi

sekaligus campur tangan pemerintah dalam mewujudkan peningkatan indeks pembangunan manusia di Indonesia.

\section{Perumusan Hipotesis}

Berdasarkan kerangka berpikir tersebut maka hipotesis yang akan di bahwa adalah "Tingkat pengeluaran

\section{METODOLOGI PENELITIAN}

Penelitianini bertujuan untuk mendapatkan data atau fakta yang 
absolut, benar dan dapat dipercaya dari permasalahan yang diajukan, yaitu:

1. Mengetahui seberapa besar pengaruh pengeluaran pemerintah daerah pada sektor pendidikan terhadap indeks pembangunan manusia.

2. Mengetahui seberapa besar pengaruh pengeluaran pemerintah daerah pada sektor kesehatan terhadap indeks pembangunan manusia.

3. Mengetahui seberapa besar pengaruh pengeluaran pemerintah daerah pada sektor pendidikan dan pengeluaran pemerintah pada sektor kesehatan terhadap indeks pembangunan manusia.

Penelitian ini dilaksanakan dengan mengambil data pengeluaran pemerintah pada sektor pendidikan dan kesehatan, beserta data indeks pembangunan manusia pada seluruh propinsi di Indonesia di Badan Pusat Statistik.

Data yang digunakan adalah data time series (rentang waktu) yaitu data jumlah pengeluaran pemerintah pada sektor pendidikan dan kesehatan setiap provinsi di Indonesia, beserta data indeks pembangunan manusia setiap provinsi di Indonesia pada tahun 20072008. Penelitian ini dilaksanakan selama 3 bulan yakni dari bulan AprilJuni 2010.
Metode yang digunakan dalam penelitian ini adalah metode statistika induktif (statistika inferensial). statistika inferensial adalah statistika yang mempuyai tugas menganalisis dan mengambil kesimpulan serta membuat keputusan berdasarkan penganalisisan yang telah dilakukan, yang termasuk ke dalam statistika inferensial ini antara lain melakukan prediksi dan pengujian hipotesis. Statistika inferensial berkenaan dengan permodelan data dan melakukan pengambilan keputusan berdasarkan analisis data, misalnya melakukan pengujian hipotesis, melakukan estimasi pengamatan masa mendatang (estimasi atau prediksi), membuat permodelan (korelasi, regresi, anova, deret waktu), dan sebagainya. Statistik inferensialadalah statistik yang berkenaan dengan cara penarikan kesimpulan berdasarkan data yang diperoleh dari sampel untuk menggambarkan karakterisktik atau ciri dari suatu populasi. Dengan demikian dalam statistik inferensial dilakukan suatu generalisasi (perampatan atau memperumum) dan hal yang bersifat khusus (kecil) ke hal yang lebih luas (umum). Oleh karena itu, statistik inferensial disebut juga statistik induktif atau statistik penarikan kesimpulan.

Teknik pengambilan data dalam penelitian ini adalah dengan 
menggunakan teknik panel data. Data panel atau panel data adalah gabungan dari data time series (antar waktu) dan data cross section (antar individu/ruang). Untuk menggambarkan panel data secara singkat, misalkan pada data cross section, nilai dari satu variabel atau lebih dikumpulkan untuk beberapa unit sampel pada suatu waktu-waktu. Dalam panel data, unit cross section yang sama di-survey dalam beberapa waktu 3 Regresi dengan menggunakan panel data, memberikan beberapa keunggulan dibandingkan dengan pendekatan standar cross section dan time series.

Data yang Data yang digunakan dalam penelitian ini adalah dengan menggunakan cross section dari 28 provinsi yang ada di Indonesia, dan time series selama 2 tahun yaitu dari tahun 2007 - 2008. Dengan jumlah data secara keseluruhan dengan menggabungkan cross section dan time series dalam bentuk panel data menjadi sebanyak 56 data analisis.

\section{HASIL PENELITIAN DAN}

\section{PEMBAHASAN}

\section{Uji Persyaratan Analisis}

\section{Uji Linearitas}

Berdasarkan diagram pencar pada Gambar IV.4 hal 97 diagram tersebut tidak membentuk suatu pola tertentu (misal: parabola, kubik dan sebagainya), dimana untuk mencapai suatu pola, tentu titik-titik yang ada harus membentuk garis melengkung (non-linier). Jadi asumsi linearitas terpenuhi.

\section{Uji Normalitas}

Dari gambar IV.5 pada halaman 97terlihat titik-titik distribusi terletak di sekitar garis lurus diagonal, sehingga dapat disimpulkan bahwa distribusi Indeks Pembangunan Manusia sesuai dengan distribusi uji. Jadi model regresi berdistribusi normal.

\section{Persamaan Regresi}

Sebelum menginterpretasikan persamaan regresi yang didapat, maka akan dilakukan terlebih dahulu pemeriksaan model regresi. Pemeriksaan model regresi umumnya dimulai dari tabel ANOVA, merupakan hasil pengujian terhadap koefisien regresi secara bersama-sama. Berdasarkan tabel VI.2 pada halaman 94 terlihat bahwa koefisien intercept adalah 42,955 sedangkan koefisien slope untuk pengeluaran pemerintah pada sektor pendidikan adalah 0,902 dan pengeluaran pemerintah pada sektor kesehatan adalah 0,198. Dari koefisien tersebut, dapat dituliskan persamaan regresi sebagai berikut: 
$Y=42,955+0,902 \operatorname{LnX}_{1}+0,198 \operatorname{Ln} X_{2}$

$\mathrm{Y}=$ Indeks Pembangunan

Manusia (IPM)

$\mathrm{X}_{1}=$ Pengeluaran Pemerintah

pada Sektor Pendidikan

$\mathrm{X}_{2}=$ Pengeluaran Pemerintah

pada Sektor Kesehatan

Ln = Logaritma Natural

\section{Koefisien Korelasi Parsial}

Pada tabel IV.3pada halaman 94 terlihat bahwa nilai korelasi variabel secara parsial sebesar 0,407 untuk korelasi antara pengeluaran pemerintah pada sektor pendidikan dengan pengeluaran pemerintah pada sektor kesehatan. Korelasi tersebut dapat digolongkan sebagai korelasi yang sedang. Sementara, koefisien korelasi parsial antara pengeluaran pemerintah pada sektor kesehatan dengan pengeluaran pemerintah pada sektor pendidikanadalah 0,056 . Korelasi tersebut juga digolongkan sebagai korelasi yang sangat rendah

\section{Koefisien Korelasi Simultan}

Pada tabel diatas IV.4pada halaman 94nilai $R$ adalah 0,432. Ini berarti pengaruhpengeluaran pemerintah pada sektor kesehatan, pengeluran pemerintah pada sektor pendidikan secara simultan denganIPM adalah 43,2\%. Korelasi tersebut dapat digolongkan sebagai korelasi yang sedang.

\section{Uji Hipotesis}

\section{Uji Keberartian Regresi}

Persamaan regresi yang telah terbentuk harus diuji apakah persamaan regresi tersebut signifikan atau tidak. Untuk menguji keberartian koefisien regresi dapat dilihat dari nilai $F_{\text {hitung }}$, bila $F_{\text {hitung }}>F_{\text {tabel }}$, dan signifikansi $<0,05$ maka persamaan regresi adalah signifikan.

Dari tabel VI.5 pada halaman 95Anova tersebut, terlihat bahwa nilai

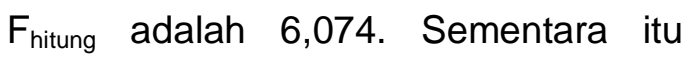
dalam tabel nilai statistik $F$ dengan derajat bebas $V_{1}=2$ dan $V_{2}=53$ pada taraf signifikan $0,05 \mathrm{~F}(0.05,2,53)$ diperoleh nilai $F_{\text {tabel }}$ sebesar 3,171626. Dengan demikian $F_{\text {hitung }}>F_{\text {tabel }}$. Hasil pengujian pada tabel diatas menunjukkan bahwa regresi signifikan antara IPM dengan pengeluaran pemerintah pada sektor pendidikan,dan pengeluaran pemerintah pada sektor kesehatan.

\section{Uji Keberartian Koefisien Korelasi Parsial \\ Uji keberartian korelasi secara} parsial dapat dilihat dari tabel IV.6pada halaman 95nilai $t_{\text {hitung }}$ pada tabel. Nilai $t_{\text {hitung. }}$ Jikat $t_{\text {hitung }} t_{\text {tabel }}$ maka Ho ditolak dan Jika $t_{\text {hitung }} t_{\text {tabel }}$ maka Hoditerima. Untuk $t_{\text {hitung }}$ pengeluaran pemerintah pada 
sektor pendidikan adalah 3,023 dan 0,412 untuk pengeluaran pemerintah pada sektor kesehatan. Sedangkan nilai $t_{\text {tabel }}(0,05 ; 53)$ adalah2.005746. Maka dapat disimpulkan koefisien korelasi secara parsial antara pengeluaran pemerintah pada sektor pendidikan dengan IPM adalah signifikan (Ho ditolak, berarti berpengaruh). Sedangkan,koefisien korelasi secara parsial antara pengeluaran pemerintah pada sektor kesehatan dengan IPM adalah tidak signifikan.

\section{Uji Keberartian Koefisien Korelasi} Simultan

Uji keberartian korelasi secara simultan dapat dilihat dari tabel VI.7pada halaman 95 nilai $F_{\text {hitung }}$ yang terdapat pada tabel. Nilai $F_{\text {hitung }}$ adalah 6,074 dengan nilai sig. 0.004 . Sedangkan nilai $F_{\text {tabel }}$ adalah 3,171626, sehingga diperolah nilai $F_{\text {hitung }}>F_{\text {tabel, }}$ maka dapat dinyatakan koefisien korelasi serempak (R) adalah signifikan.

\section{Koefisien Determinasi $\left(R^{2}\right)$}

Berdasarkan tabellV.8 pada halaman 96 diperoleh angka $R^{2}(R$ Square) sebesar 0,186. Hal ini menunjukkan bahwa variasi sumbangan pengaruh variabel independen (pengeluaran pemerintah pada sektor pendidikan,dan pengeluaran pemerintah pada sektor kesehatan) terhadap variabel dependen (Indeks Pembangunan Manusia) termasuk sangat rendah. Hal ini berarti sebanyak $18,9 \%$ variasi atau perubahan dalam IPM dapat dijelaskan oleh perubahan atau variasi dari pengeluaran pemerintah pada sektor pendidikan,dan pengeluaran pemerintah pada sektor kesehatan. Sedangkan sisanya $81,1 \%$ diterangkan oleh faktor-faktor lain.

\section{Uji Asumsi Klasik}

Pengujian asumsi klasik merupakan syarat utama untuk menilai persamaan regresi yang digunakan sudah memenuhi syarat utama untuk menilai apakah persamaan regresi yang digunakan sudah memenuhi syarat BLUE (best linear unblased estimator).

\section{Uji Heterokedastisitas}

Untuk mendeteksi ada tidaknya heteroskedastisitas, dapat dengan melihat pola titik-titik pada scatterplot regresi lampiran halaman 96. Karena titik-titik menyebar dengan pola yang tidak jelas di atas dan di bawah angka 0 pada sumbu $Y$, maka tidak terjadi masalah heterokedasitas. 


\section{Uji Multikolinearitas}

Untuk melihat apakah terdapat multikolinieritas dalam model regresi dapat dilihat dalam tabel VI.9 pada halaman 96yang menunjukkan bahwa nilai tolerance lebih dari 0,1 yaitu sebesar 0,847 dan nilai VIF kurang dari sepuluh yaitu sebesar 1,181 . Ini berarti menunjukkan tidak adanya multikolinearitas.

\section{Uji Autokorelasi}

Autokorelasi dapat diukur melalui nilai Durbin-Watson (DW). Pada tabel VI.10pada halaman 96dapat dilihat nilai Durbin-Watson (DW) yaitu sebesar 1,997. Berdasarkan tabel statistik d Durbin-Watson dengan $\mathrm{k}=2$ dan $n=56$, diperoleh $d_{L}$ sebesar 1,49 dan $d_{u}$ sebesar 1,64. Nilai tersebut berada pada interval $\mathrm{d}_{\mathrm{u}}<\mathrm{d}<4-\mathrm{d}_{\mathrm{u}}$ $(1,64<1,997<2,003)$ atau dengan kata lain Hoditerima, sehingga dapat dinyatakan tidak terdapat autokorelasi dalam model regresi.

\section{Interpretasi Hasil Penelitian}

Model statistik fungsi permintaan yang dispesifikasi sesuai dengan tujuan penelitian yang telah dikemukakan pada bab terdahulu adalah:

$Y=b_{0}+b_{1} \operatorname{Ln} X_{1}+b_{2} \operatorname{Ln} X_{2}+e \ldots \ldots$ (i)

Dimana:

$\mathrm{Y}=$ Indeks Pembangunan Manusia (IPM)
$\mathrm{X}_{1}=$ Pengeluaran Pemerintah pada Sektor Pendidikan

$\mathrm{X}_{2}=$ Pengeluaran Pemerintah pada Sektor Kesehatan

$\mathrm{b}_{1} \quad=$ elastisitas harga barang itu sendiri

$\mathrm{b}_{2} \quad=$ elastisitas silang

Ln = Logaritma Natural

Model tersebut diproses dengan menggunakan program statistik (software) yaitu Statistical Package for Social Science (SPSS) Versi 17.0. Model di atas diestimasi dengan menggunakan metode estimasi kuadrat terkecil (Ordinary Least Square Method - OLS). Metode OLS digunakan dalam mengestimasi model, karena metode tersebut menghasilkan "parameter estimates" yang terbaik, linear, unbiased dan efisien (Best, Linear, Unbiased, Estimator - BLUE) jika asumsi klasik dipenuhi.

Hasil estimasi untuk persamaan (i) sebagai berikut:

$Y=42,955+0,902 \operatorname{LnX} 1+0,198 \operatorname{LnX}_{2}$

$\mathrm{R}^{2} \quad=0,186$

Adjusted $R^{2}=0,156$

F-Statistic $=6,074$

$\mathrm{D}-\mathrm{W}=1,997$

Signifikansi $\mathrm{a}=0,004$

Pada bagian ini akan dijelaskan hasil estimasi fungsi permintaan berdasarkan angka-angka statistik (hasil perhitungan) dan tinjauan dari sudut ekonomi. Dari sudut statistik akan 
dijelaskan kecocokan model dalam merepresentasikan data empiris, signifikansi variabel independen yang dispesifikasi dalam mempengaruhi dependen, korelasi antara variabel independen itu sendiri, dan korelasi runtun (serial correlation). Dari sudut ekonomi akan menunjukkan apakah secara kualitatif dan kuantitatif ada kecocokan model dengan teori yang digunakan dalam penelitian ini dan arti nilai-nilai yang diperoleh dalam model tersebut. Output SPSS untuk persamaan regresi yang pertama dapat dilihat pada lampiran ke 3 pada halaman 100.

Berdasarkan hasil estimasi model di atas, maka dapat dikemukakan beberapa hal penting yang berhubungan dengan parameter yang diestimasi, ketepatan regresi (goodness of fit), multikolinearitas (multicollinearity), dan korelasi runtun (serial correlation). Tinjauan atas hasil estimasi secara statistik ini berguna untuk menentukan apakah variabelvariabel bebas (independent) yang dispesifikasi dalam model tersebut secara berarti (significance) mempengaruhi variabel terikat (dependent) dan kesesuaian model dalam merepresentasikan kejadiankejadian empiris.

Persamaan (i) yang mewakili fungsi indeks pembangunan manusia permintaan menunjukkan hasil statistik $F$ hitung sebesar 6,074.. Nilai F hitung ini lebih besar dari Ftabel derajat kebebasan $(\mathrm{k}-1, \mathrm{n}-\mathrm{k})$ atau $(2,53)$ pada tingkat kepercayaan 95\% (Ftabel = $3,171626)$, ini berarti bahwa variabel bebas (pengeluaran pemerintah pada sektor pendidikandan pengeluaran pemerintah pada sektor kesehatan) secara bersama-sama berpengaruh terhadap variabel terikat (indeks pembangunan manusia).

Untuk melihat variabel bebas mana yang signifikan secara statistik mempengaruhi indeks pembangunan manusia dapat dilihat dari besarnya nilai $\mathrm{t}$ hitung dengan membandingkan nilai t tabel pada hasil SPSS. Dengan menggunakan tingkat kepercayaan $90 \%$ atau tingkat signifikansi sebesar $5 \%$ dengan derajat kebebasan sebesar 53 ( $\mathrm{t}$ tabel $=2.005746$ ), ternyata pengeluaran pemerintah pada sektor pendidikanberpengaruh signifikan terhadap variabel terikat $Y$ (indeks pembangunan manusia) karena t hitung pengeluaran pemerintah pada sektor pendidikansebesar3.023. Sedangkan, pengeluaran pemerintah pada sektor kesehatantidak berpengaruh terhadap variabel terikat $Y$ (indeks pembangunan manusia) karena $t$ hitung pengeluaran pemerintah pada sektor kesehatan sebesar0,412. 
Dalam realitanya IPM di Indonesia tidak dipengaruhi oleh pengeluaran pemerintah pada sektor kesehatan. Hal tersebut terjadi, karena pada periode tahun 2007-2008, anggaran pemerintah untuk sektor kesehatan masih sangat kecil. Secara keseluruhan, Indonesia mengeluarkan kurang dari 3 persendari PDB-nya untuk sektor kesehatan (terdiri dari 2 persen pengeluaran swastadan 1 persen pengeluaran pemerintah). Pembiayaan kesehatan di Indonesia termasuk paling kecil dibanding negara tetangga. Menurut data World Health Organization (WHO) tahun 2000. Indonesia memang lebih baik dari Vietnam yang menduduki urutan 182, Indonesia menduduki urutan 154 dari 191 negara. Sedangkan negara lain, India menduduki urutan 133, Malayasia menduduki urutan 93, Thailand menduduki urutan ke 64 dan Pilipina menduduki urutan 124 dan Srilangka 138. Sebagian besar dari biaya tersebut berasal dari non pemerintah, yaitu sekitar 70 sampai 75 persen. Padahal, WHO menganjurkan anggaran kesehatan minimal lima persen dari total Gross National Product (GNP). Sejak Indonesia merdeka tidak pernah anggaran kesehatan mencapai 2,5 persen dari GNP.
Bahkan, jika dilihat dari alokasi anggaran pemerintah disetiap propinsi di Indonesia, anggaran pengeluaran pemerintah untuk kesehatan, masih jauh dibawah jika dibandingkan dengan alokasi pengeluaran ataupun belanja pemerintah lainnya. Hal inilah yang menyebabkan mengapa di Indonesia masih belum berpengaruh pengeluaran pemerintah pada sektor kesehatan terhadap IPM. Secara teknis, pengeluaran pemerintah pada sektor kesehatan ditingkat propinsi hanya memiliki batas ruang dan andil yang kecil. Karena penggunaan dana kesehatan lebih dominan pada kabupaten. Sedangkan, cakupan dalam penelitian ini adalah propinsi. pemerintah pusat dan pemerintah kabupaten/kota masing-masing diperkirakan mengelola sekitar 40-45 persen, sedangkan pemerintahprovinsi mengelola sekitar 15 persen dari pengeluaran publik untuk sektor kesehatan.

Pada tahun 2002, Gion Muhammad Kharismawan meneliti tentang pengaruh pengeluaran pemerintah terhadap IPM di daerah Jawa Timur, dan hasilnya membuktikan bahwa pengeluaran pemerintah pada sektor pendidikan dan kesehatan tidak signifikan terhadap IPM. Pengeluaran pemerintah pada sektor kesehatan belum signifikan terhadap IPM karena 
pada tahun tersebut, pengeluaran pemerintah pada sektor pendidikan belum mencapai $20 \%$. Bila ditinjau dari sudut ketepatan model dalam merepresentasikan indeks pembangunan manusia, maka model tersebut cocok (fit) dengan kejadian empiris yang ditunjukkan oleh rendahnya nilai koefisien determinasi. $\mathrm{R}^{2}$ maupun nilai Adjusted $\mathrm{R}^{2}$ yaitu masing-masing sebesar 0,186 dan 0,156 . Keadaan ini dapat diartikan bahwa 18,9 persen variasi daripada variabel terikat dijelaskan oleh variabel bebas, sedangkan 81,1 persen ditentukan oleh faktor-faktor (variabelvariabel) lainnya yang tidak dimasukkan ke dalam model IPM di atas.

Dalam penelitian ini, peneliti menggunakan teknik purposive sampling dalam pengambilan data. Peneliti juga menerapkan Extrem Outlier(Outlier Data) pada beberapa sample yang dinilai kurang merepresentasikan sample dan data yang lain. Pengambilan data penghitungannya berbentuk cross section, maksudnya adalah data silang tepat atau pada titik tertentu saja dengan observasi atas sejumlah variable (individu, kota, propinsi, negara, atau industri).Teknik pengambilan data dalam penelitian ini hanya meliputi 56 propinsi. Terdapat 5 propinsi yang ditiadakan, sehingga dalam periode tahun 2007-2008 terdapat 10 propinsi yang ditiadakan, yaitu Aceh, DKI Jakarta, Jawa Tengah, Jawa Timur, dan Papua. Kelima propinsi tersebut ditiadakan dalam proses penelitian dengan tidak tanpa alasan berarti, adapun penyebab peniadaan kelima propinsi tersebut adalah Aceh, DKI Jakarta, Jawa Tengah dan Jawa Timur adalah karena peneliti melakukan penilaian secara komprehensif terhadap semua pengeluaran pemerintah daerah pada sektor pendidikan dan kesehatan, dan kelima kota tersebut masuk kedalam pengelolaan anggaran yang masih belum efektif. Karena pengeluaran pemerintah pada sektor pendidikan dan kesehatan pada lima kota tersebut sangat tinggi, namun perolehan IPM masih sangat rendah. Hal tersebut merupakan eksternalitas negatif dari kinerja pemda dalam hal efektivitas dan efisiensi penggunaan anggaran ataupun belanja pemerintah.

Sedangkan, untuk Propinsi Papua anggaran pemerintah daerah pada sektor pendidikan dan kesehatan sudah tersedia dalam jumlah nominal yang sangat besar, namun faktor topografi alam dan luasnya wilayah Papua mengindikasikan belum efektifnya pengelolaan anggaran pemerintah tersebut.Selanjutnya 
penilaian terhadap estimator atau parameter yang diestimasi dapat diinterpretasikan atau tidak sangat bergantung kepada apakah terdapat korelasi yang kuat antara variabel bebas di dalam model tersebut. Apabila keadaan ini terjadi berarti terdapat multikolinearitas antara variabel bebas yang dispesifikasi dalam model tersebut. Terdapatnya multikolinearitas antara variabel bebas menimbulkan kesulitan dalam menginterpretasikan koefisien yang diestimasi atas pengaruhnya terhadap variabel terikat.

Berdasarkan hasil penilaian terhadap informasi statistik yang diperoleh dari model yang digunakan dalam penelitian menunjukkan tidak adanya indikasi multikolinearitas yang dicerminkan dari tolerance dan VIF. Jika nilai tolerance hitung lebih besar dari 0,1 dan nilai VIF lebih kecil dari 10, maka tidak terjadi multikolinearitas. Dalam penelitian ini, tidak menunjukkan adanya multikolinearitas karena nilai tolerance sebesar 0,847 dan VIF sebesar 1,181 .

Di dalam studi yang menggunakan data runtun waktu (time series), persoalan yang mungkin muncul adalah korelasi runtun (serial correlation) yaitu adanya hubungan antara kesalahan (error) observasi sekarang dengan kesalahan observasi sebelumnya. Dengan kata lain kesalahan observasi yang lalu dibawa ke observasi sekarang. Adanya serial correlation tidak berdampak pada "unbiasedness" dan "consistency" tetapi membawa dampak pada efisiensi. Ini berarti bahwa "standard error of parameter estimates" yang diperoleh dengan menggunakan metode OLS lebih kecil daripada seharusnya. Keadaan ini menunjukkan adanya bias ke bawah (biased downward) pada "standard error of parameter estimates", sehingga berakibat pada penolakan hipotesis nol yang seharusnya diterima

Berdasarkan nilai statistik untuk Durbin-Watson yang diperoleh dari hasil estimasi model indeks pembangunan manusia dengan menggunakan metode OLS adalah sebesar 1,997. Dengan menggunakan perhitungan $\quad \mathrm{d}_{\mathrm{u}}<\mathrm{d}<4-\mathrm{d}_{\mathrm{u}}$ $(1,64<1,997<2,003) \quad$ maka menunjukkan tidak terjadi autokorelasi dalam persamaan regresi.

Pada bagian diatas telah dijelaskan bagaimana pengaruh variabel bebas (pengeluaran pemerintah pada sektor pendidikandan pengeluaran pemerintah pada sektor kesehatan) terhadap variabel terikat (IPM) secara statistik. Juga telah dibahas apakah asumsi-asumsi klasik yang diterapkan pada model tersebut telah dipenuhi. Pada bagian ini akan 
sudut pandang (tinjauan) ekonomi ataupun realitanya di lapangan, sesuai dengan model IPM yang telah dispesifikasi sebelumnya.

Pengeluaran pemerintah daerah pada sektor pendidikan adalah bagian anggaran dari pemerintah daerah yang dapat diartikan sebagai rencana keuangan yang mencerminkan pilihan kebijaksanaan untuk suatu periode pengeluaran yang dikategorikan sebagai pengeluaran untuk investasi/belanja pemerintah dalam investasi pembangunan pada sektor pendidikan. Jika dikaitkan dengan IPM, maka jika pengeluaran pemerintah daerah pada sektor pendidikan naik maka IPM akan naik, sedangkan jika pengeluaran pemerintah daerah pada sektor pendidikan turun maka IPM akan turun atau memiliki koefisien positif.

Hasil penelitian menunjukkan bahwa adanya hubungan positif antara IPM denganpengeluaran pemerintah daerah pada sektor pendidikan. Keadaan ini dapat dilihat pada persamaan (i) di atas dimana tanda koefisien variabel $\mathrm{i}$ adalah positif yaitu sebesar 0,902.Koefisien dalam nilai sebesar 0,902 ini menunjukkan bahwa perkembangan pengeluaran pemerintah pada sektor pendidikan sangatsignifikan atau sangat berpengaruh terhadap perubahanIPM.. Setiap adanya kenaikanpengeluaran pemerintah daerah pada sektor pendidikansebesar satu persen akan menaikkan perkembangan IPM sebesar 90,2 . Sebaliknya jika tingkat pengeluaran pemerintah daerah pada sektor pendidikanturun sebesar satu persen, maka IPM hanya akan turun sebesar 90,2. Hal ini dapat diperkuat dengansecara statisitik berpengaruh secara signifikan terhadap perkembangan IPM pada tingkat kepercayaan 95\%. Senada dengan kebijakan pemerintah untuk menaikkan anggaran pendidikan sebesar $20 \%$ dari APBN, dan harus diikuti oleh pemerintah daerah dengan menaikkan anggaran pendidikan sebesar $20 \%$ dari APBD, maka semakin mempengaruhi pengeluaran pemerintah daerah pada sektor pendidikan terhadap IPM. Meskipun jumlah nominal setiap propinsi memiliki angka yang berbedabeda, namun proporsi anggaran pendidikan disetiap propinsi merupakan $20 \%$ dari total anggaran APBD. Hal tersebutlah yang menyebabkan secara teknis, pengeluaran pemerintah pada sektor pendidikan berpengaruh secara positif terhadap indeks pembangunan manusia di Indonesia.

Pengeluaran pemerintah pada sektor kesehatan adalah bagian anggaran dari pemerintah yang dapat diartikan sebagai rencana keuangan yang mencerminkan pilihan 
kebijaksanaan untuk suatu periode pengeluaran yang dikategorikan sebagai pengeluaran untuk investasi/belanja pemerintah dalam investasi pembangunan pada sektor kesehatan. Hasil penelitian menunjukkan koefesien yang positif, berarti pengaruh pengeluaran pemerintah daerah pada sektor kesehatan terhadap IPM adalah positif. Apabila pengeluaran pemerintah daerah pada sektor kesehatan mengalami kenaikan maka secara tingkat perkembangan IPM juga akan meningkat. Hal ini sesuai sudah sesuai dengan teori yang ada. Perkembangan indeks pembangunan manusia akan semakin meningkat jika pemerintah bersedia menanamkan investasi publik dalam belanja ataupun pengeluaran pemerintah pada sektor kesehatan.

Berbeda dengan kebijakan pemerintah pada sektor kesehatan, belum ada peraturan yang menegaskan ataupun mewajibkan bahwa anggaran kesehatan setidaknya mencapai 5\% dari GNP. Di tingkat nasional pun, peraturan yang telah dicetuskan oleh WHO belum bisa direalisasikan, terlebih pada tingkat propinsi yang anggaran kesehatannya masih belum mendapat prioritas seperti anggaran kesehatan. Semestinya, untuk meningkatkan kualitas manusia yang produktif tidak hanya pendidikan yang menjadi fokus perhatian dari kebijakan pemerintah, melainkan pelayanan kesehatanyang tercermin dari pengeluaran pemerintah pada sektor kesehatan juga ikut mempengaruhi kualitas manusia yang akan berujung pada peningkatan Indeks Pembangunan Manusia pada setiap propinsi di Indonesia.

Pada propinsi Gorontalo pada tahun 2008, pengeluaran pemerintah pada sektor pendidikan mencapai jumlah nominal Rp. 50.393.000.000 dan untuk sektor kesehatannyahanya sebesar Rp. 11.864.000.000. Jika dianalisis berdasarkan porsinya, pengeluaran pemerintah Gorontalo pada sektor kesehatan hanya menyentuh seperempat dari anggaran pendidikan yang dikeluarkan. Oleh karena itu, dampak secara nyatanya mempengaruhi besaran tingkat Indeks Pembangunan Manusia yang dicapai oleh propinsi Gorontalo yakni 69,29. $\mathrm{Hal}$ ini sangat berbeda dengan propinsi Sulawesi Utara, yang total anggaran pengeluaran pemerintah pada sektor pendidikannya mencapai Rp. 60.704.000.000 dan pada sektor kesehatannya mencapai $\mathrm{Rp}$. 48.212.000.000. Selisih antara besaran nominal ataupun jumlahnya tidaklah berbeda jauh, pengeluaran pada sektor kesehatannya mencapai tiga perempat atau menyentuh porsi $75 \%$ dari 
pengeluaran pemerintah propinsi

Sulawesi Utara pada sektor pendidikan.

Hal inilah yang memberikan efek positif terhadap perolehan Indeks Pembangunan Manusia propinsi Sulawesi Utara yang mencapai 75,16. Dengan kata lain, masih banyak propinsi di Indonesia yang harus meningkatkan pengeluarannya pada sektor publik, terlebih pada sektor kesehatan guna meningkatkan kualitas manusia dan berujung pada peningkatan Indeks Pembangunan Manusia pada setiap propinsi di Indonesia

Keadaan ini dapat dilihat dari tanda pada

koefisien variabelpengeluaran pemerintah daerah pada sektor kesehatan yang mempunyai tanda positif dengan nilai koefisien sebesar 0,198, Angka ini mempunyai arti apabila pengeluaran pemerintah daerah pada sektor kesehatan naik satu persen, maka perkembangan IPM naik sebesar 19,8. Sebaliknya, apabila pengeluaran pemerintah daerah pada sektor kesehatanturun sebesar satu persen, maka perkembangan IPM turun sebesar19,8,namun besaran koefesien tersebut menerangkan bahwa pengaruh pengeluaran pemerintah daerah pada sektor kesehatan terhadap IPM masih rendah. Hal ini disebabkan karena, belanja atau pengeluaran pemerintah daerah masih rendah jika dibandingkan dengan belanja atau pengeluaran pemerintah pada sektor lainnya. Pengeluaran pemerintah pada sektor kesehatan secara lingkup nasional pada periode 2007-2008 masih kurang dari 3\% PDB. Dengan demikian terlihat adanya kesenjangan antara keinginan pemerintah untuk menaikkan indeks pembangunan manusia, sementara dari sisi investasi publik pemerintah disektor kesehatan masih relatif rendah.

Pada bagian ini akan dibentuk dan disesuaikan pembentukkan model regresi yang baik dan sesuai. Persyaratan model regresi yang baik, mengharuskan koefesien regresi harus signifikan, yang pengujiannya dilakukan dengan uji $\mathrm{T}$, dengan hasil perhitungan $\mathrm{T}$ hitung > $\mathrm{T}$ tabel. Sedangkan dari hasil analisis regresi sebelumnya, persamaan regresi belum memenuhi standar persamaan regresi yang baik dan sesuai dengan teori yang ada, bahwa pengujian korelasi pasrsial haruslah signifikan. Hasil telaah perhitungan statistik dengan menggunakan SPSS, menjelaskan hasil uji parsial antara variabel bebas pengeluaran pemerintah pada sektor kesehatan tidak signifikan terhadap variabel terikat Indeks Pembangunan Manusia. Telah disebutkan alasan realitis, teknis dan kejadian empiris 
yang menyebabkan mengapa hal tersebut terjadi. Oleh karena itu, untuk membentuk suatu fungsi yang baik dan bisa menjelaskan seberapa besar pengaruh perubahan variabel bebas terhadap variabel terikat, hanyalah variabel bebas pengeluaran pemerintah pada sektor pendidikan saja yang bisa menjelaskan pengaruh perubahannya terhadap variabel terikat Indeks Pembangunan Manusia. Sedangkan, variabel pengeluaran pemerintah pada sektor kesehatan di Indonesia belum bisa melihat besaran pengaruh perubahan terhadap variabel terikat Indeks Pembangunan Manusia. Pada akhirnya, akan diperoleh suatu model yang secara teoritis dan empiris menjelaskan faktor yang mempengaruhi Indeks Pembangunan Manusia pada setiap propinsi di Indonesia berdasarkan periode waktu yang diamati.

Hasil dari penelitian ini menunjukkan bahwa model sederhana (i) dalam bentuk logaritma natural dalam merepresentasikan IPM secara statistik signifikan dan mengisyaratkan bahwa keberadaan pengeluaran pemerintah pada sektor kesehatan masih belum merupakan faktor yang perlu dipertimbangkan dalam melihat IPM, Karena variabel pengeluaran pemerintah pada sektor kesehatan tidak berpengaruh nyata dalam IPM.

\section{KESIMPULAN DAN SARAN}

\section{Kesimpulan}

Berdasarkan hasil pengolahan data pengeluaran pemerintah daerah pada sektor pendidikan dan kesehatan dengan Indeks Pembangunan Manusia, maka dapat diambil kesimpulan bahwa:

Tingkat pengeluaran pemerintah daerah pada sektor pendidikan memiliki pengaruh secara signifikan terhadap IPM, dimana setiap terjadi perubahan pada pengeluaran pemerintah daerah pada sektor pendidikan maka akan diikuti oleh perubahan IPM.

Pengeluaran pemerintah pada sektor kesehatan di Indonesia hanya berkisar 1 persen dari PDB, sedangkan pengeluaran swasta kurang dari 2 persen. Padahal, WHO memberikan batasan pengeluaran kesehatan setiap negara minimal 5 persen dari PDB. Oleh karena tingkat pengeluaran pemerintah daerah pada sektor kesehatan belum mencapai 5 persen dari PDRB, maka pengeluaran pemerintah daerah pada sektor kesehatan tidak berpengaruh secara signifikan terhadap IPM. Pengeluaran pemerintah pada sektor kesehatan di Indonesia masih sangat rendah dibandingkan dengan tingkat pengeluaran pemerintah lainnya.

Tingkat pengeluaran pemerintah daerah pada sektor pendidikan dan kesehatan secara serempak 
memberikan pengaruh positif dengan ditunjukkan koefesien yang positif pada dua variabel bebas tersebut, sehingga tetap memberikan pengaruh yang signifikan terhadap IPM, meskipun dengan tingkat pengaruh yang rendah.

\section{Saran}

Atas dasar implikasi dari hasil pembahasan diatas, maka peneliti memberikan beberapa saran sebagai berikut :

1. Diharapkan bagi semua instansi, baik pemerintah yang berada di pusat maupun daerah untuk terus meningkatkan pengeluaran pemerintah pada sektor pendidikan dan terlebih pada sektor kesehatan, sehingga dapat meningkatkan Indeks Pembangunan Manusia.

2. Agar masyarakat pada khususnya turut meningkatkan kualitas diri dalam peningkatan pembangunan manusia di Indonesia

\section{DAFTAR PUSTAKA}

Abdoel, Jalan Suparman dan Rozy Munir. 1993. Perkembangan Pembangunan Manusia di Indonesia. Jakarta: Puslit.
Pranata

Pembangunan

Universitas Indonesia

Bastian, ndra. 2006. Sistem Perencanaan dan Penganggaran Pemerintah Daerah di Indonesia, Jakarta:Salemba Empat

Danim, Sudarwan. 1995. Transformasi Sumber Daya Manusia.Jakarta:Bumi Aksara

Djalal, Nachrowi dan Hardius Usman. 2008. Penggunaan Teknik Ekonometri. Jakarta:Rajawali Press

Gozhali, Imam. Ekonometrika Teori, Konsep dan Aplikasi Dengan SPSS 17, (Jakarta: Erlangga, 2009)

Husein Umar.2001.Riset Akuntansi, (Jakarta: Gramedia Pustaka Utama)

Michael P Todaro, 1995. Economic Development In The Third World, Fourth Edition. Jakarta: Erlangga Dengan Macintosh LSII

Musgrave, Richard A dan Peggy B. Musgrave. 1993. Keuangan Negara Dalam Teori dan Praktek. Erlangga: Jakarta 
Rudi Yuwono, Nugroho. 1994. Pelajaran Statistik untuk SMA dan Sederajat .Yogyakarta:BPFE

Sitompul, Rudy. 1993. Keuangan Negara Perekonomian Sektor Publik. Erlangga: Jakarta

Soetrisno. 2001. Dasar-Dasar IImu Keuangan Negara, Yogyakarta: Fakultas Ekonomi Universitas Gadjah Mada

Suryana, 2000. Ekonomi Pembangunan Problematika dan Pendekatan. Salemba Empat: Jakarta

Swasono, Sri Edi. 2009. Indonesia dan Doktrin Kesejahteran Sosial. Yayasan Hatta:Jakarta 2008, Ekspose Ekonomika, Pusat Studi Ekonomi Pancasila UGM: Yogyakarta

Tjiptoherijanto,Prijono.1989.Untaian Pembangunan Sumberdaya
Manusia.Jakarta : FEUI Tjiptoherijanto, Prijono. 1996. Sumber Daya Manusia Dalam Pembangunan Nasional, Fakultas Ekonomi Ul: Jakarta
Martinus Nanang. 1999. Reformasi Paradigma Pembangunan.Jurnal Sosial-Politika. Samarinda: Fakultas IImu Sosial.

Ulber Silalahi. 2003. Relevansi Kebijakan Human-Centered Development dan Perbaikan kualitas Pendidikan dalam Pengembangan Kualitas Sumber Daya Manusia Indonesia, Jurnal Ekonomi Pembangunan. Jakarta: LIPI,

Zahli Rusli. 2000. Sumber Daya Manusia dalam Otonomi Daerah, Jurnal Kajian Masalah Ekonomi Pembangunan,Jakarta:LIPI

Edy Suandy Hamid. 2002. Indeks Pembangunan Manusia dan Pengeluaran Konsumsi Masyarakat Study Kasus: Yogyakarta, Jurnal Ekonomi Pembangunan. Jakarta: LIPI

M.L Jhingan. 2007. Ekonomi Pembangunan dan Perencanaan. Jakarta:Raja Grafindo Persada

Aswatini Raharto, Peranan Pendidikan dalam Pembangunan Manusia, Jurnal Kajian Ekonomi dan Pembangunan, (Bandung: 
Fakultas Ekonomi Universitas Islam Bandung,2004)

Budi D. Sinulingga, Analisis Pengaruh Distribusi APBD Terhadap Indeks Pembangunan Manusia, Jurnal IImu Administrasi Negara, (Jakarta:LIPI, 2008), hal.106

www.bps.go.id di akses pada 1 April 2010 http://www.jurnalnet.com/konten.php?n ama $=$ BeritaUtama\&topik $=12 \& \mathrm{id}=$ 1060 diakses 1 April 2010

http://els.bappenas.go.id/upload/other/K esehatan\%20sebagai\%20Investa si\%20dan\%20Hak\%20Asasi\%20 Manusia.html

Budiarto Shambazy, Si Gembala Sapi, Harian Kompas, Sabtu, 5 April 2008 